\title{
The Relationship between Trade Openness, Economic Growth, Exchange Rate and Tariff Rate: Evidence from Northeast Asia
}

\author{
Anh Tru Nguyen \\ Vietnam National University of Agriculture, Trau Quy, Gia Lam, Ha Noi, Viet Nam. \\ nguyenanhtru@vnua.edu.vn
}

\begin{abstract}
The article aims to investigate the relationship between trade openness, economic growth, exchange rate and tariff rate in three Northeast Asian countries between 1998 and 2017 using a vector autoregressive model. We found that GDP growth rate has a positive relationship with trade openness. Tariff rate positively affects both GDP growth rate and exchange rate. However, trade openness has a negative effect on exchange rate. We also found that there is a directional relationship running from trade openness to GDP growth rate and exchange rate; and from exchange rate to trade openness and tariff rate. There is a long run relationship among variables. Lastly, policies are recommended to accelerate economic growth and trade openness in Northeast Asia.
\end{abstract}

Keywords: Trade openness, Economic growth, Exchange rate, Tariff rate, Northeast Asia

\section{Introduction}

In East Asia, gross domestic product (GDP) of China, Japan and the Republic of Korea (Korea) accounts for more than 85 percent of the region's GDP. Therefore, cooperation among these countries has played an essential role to build an East Asia Economic Caucus (EAEC). Free Trade Agreements (FTAs) between China, Japan and Korea are expected not only to boost economic growth but also to facilitate trade and investment in the region. However, the velocity of FTA negotiation process among three countries is very low (KIEP, 2017). The efficacy and sustainability of the East Asian model of economic development should be carefully considered due to effects of the Asian financial crisis (Park, 2002). In 2017, economic growth in Northeast Asia increased by 0.4 percent compared to previous year to reach 4.6 percent. China had a faster economic growth for the first time since 2010. Consumption tended to grow faster than investment, and services was faster than industry in line with ongoing rebalancing efforts. The unemployment rate of Japan decreased to a record low. In Korea, export sectors presented a strong growth (United Nations, 2018).

Themes on trade openness and economic growth of East Asia have been discussed broadly by scholars in recent years. Park (2002) examined the model of economic development for East Asia, while others focused on investigating the relationship between trade openness and economic growth in China and Korea (Chen and Feng, 2000; Marelli and Signorelli, 2011; Turan 
and Karakas, 2016). However, none of these uses the vector autoregressive (VAR) model to examine the relationship between trade openness, economic growth, exchange rate and tariff rate of Northeast Asia. What is the relationship between trade openness, economic growth, exchange rate and tariff rate in Northeast Asia? How do these variables correlate in the shortrun and long-run? The article aims to investigate the relationship between trade openness, economic growth, exchange rate and tariff rate of three Northeast Asian countries, namely China, Japan and Korea, between 1998 and 2017. More importantly, policies are recommended to accelerate economic growth and trade openness in Northeast Asia.

The remainder of this paper is organized as follows. Section 2 presents the empirical review. Methods are presented in section 3. Section 4 presents results and discussion. Finally, conclusion and policy implications are summarized in section 5 .

\section{Empirical Review}

The theme on the relationship between trade openness and economic growth has been strongly discussed by scholars in recent years. Trade openness has a positive relationship with export sophistication in developing democracies, as they diversify away from low productivity primary products, to high productivity manufacturing and service goods in 116 countries from 1970 to 2005 (Makhlouf et al., 2015). There is a bidirectional causal relationship for both developing and Organization for Economic Cooperation and Development (OECD) countries and an increase in trade openness leads to higher economic growth between 1977 and 2011 (Idris et al., 2016). Likewise, a study by Balavac and Pugh (2016) argued that diversification may not reduce trade openness and both inflation volatility and conflict increase output volatility and however, better political institution stabilizes output in 25 countries for the period 19962010.

Further, there is a long run relationship among energy consumption per capita, trade openness, domestic credit and real GDP per capita in Turkey between 1980 and 2014. Energy consumption and financial development positively affect economic growth, but there is no significant relationship between trade openness and economic growth in the long run (Cetin, 2016). Similarly, an openness of the economy can foster FDI in Sub-Saharan Africa (SSA) (Cantah et al., 2018). Trade openness and integration in the world economy positively affect economic growth in both China and India for the last three decades (Marelli and Signorelli, 2011). Economic growth has been identified as a significant determinant contributing to expansion of private credit which leads to the growth of trade openness in India between 1991 and 2013 (Kaushal and Pathak, 2015).

The relationship between trade openness, FDI and economic growth in East Asia is also considered to debate in recent years. Park and Park (2008) assessed the relationship between regional trade agreements (RTAs) and FDI in East Asia. They found that reform of RTAs has a positive effect on FDI and most of the proposed East Asian RTAs promote intra-bloc FDI. Likewise, participation in the World Trade Organization (WTO) assists to improve economic efficiency of China. This country tends to extend protection to those industries with relatively high average wages and high value added per worker (Chen and Feng, 2000). Lastly, Turan and Karakas (2016) asserted that per capita GDP has a positive and significant effect on the government sizes for both Turkey and the Republic of Korea. Trade openness has a negative effect on government size for Turkey, but it positively affects for the Republic of Korea.

\section{Methodology}

\section{Data and Sources}

A panel dataset for the relationship between trade openness, economic growth, exchange rate and tariff rate is gathered from the database in World Development Indicators released by the World Bank. Specifically, three countries in Northeast Asia, including China, Japan, and Korea, are chosen for the 
study. A panel dataset is collected for the last two decades (1998-2017). Thus, a total of 60 observations are entered for data analysis. The panel data is used for this research because of the following advantages: (1) it benefits in terms of obtaining a large sample, giving more degree of freedom, more information, and less multicollinearity among variables; and (2) it may overcome constraints related to control individual or time heterogeneity faced by the cross-sectional data (Hsiao, 2014).

\section{The Vector Autoregressive (VAR) Model}

The VAR model is used to examine the relationship between trade openness, economic growth, exchange rate and tariff rate of three countries in Northeast Asia from 1998 to 2017. The VAR model is chosen for this study because it explains the endogenous variables solely by their own history, apart from deterministic regressors and therefore this method incorporates non-statistical a priori information (Pfaff, 2008). Further, the VAR model is a popular method in economics and other sciences since it is a simple and flexible model for multivariate time series data (Suharsono et al., 2017).

The specification of a VAR model can be defined as follows (Pfaff, 2008):

$$
Y_{t}=A_{1} Y_{t-1}+\cdots+A_{p} Y_{t-p}+\varepsilon_{t}
$$

Where: $Y_{t}$ denotes a set of $\mathrm{K}$ endogenous variables (trade openness, economic growth rate, exchange rate, and tariff rate); $A_{i}$ represents $(K \times K)$ coefficient matrices for $i=1, \ldots, p$; and $\varepsilon_{t}$ is a K-dimensional process with $\mathrm{E}\left(\mathcal{E}_{\mathrm{t}}\right)=0$.

An important characteristic of the VAR model is stability and therefore it generates stationary time series with time invariant means, variances and covariance structure, given sufficient starting values. The stability of an empirical VAR model can be analyzed by considering the companion form and computing the eigenvalues of the coefficient matrix. A VAR model may be specified as follows (Pfaff, 2008):

$$
\varepsilon_{t}=A \varepsilon_{t-1}+V_{t}
$$

Where: $\varepsilon_{t}$ denotes the dimension of the stacked vector; $A$ is the dimension of the matrix $\left(K_{p} x\right.$ $\left.\mathrm{K}_{\mathrm{p}}\right)$; and $\mathrm{V}_{\mathrm{t}}$ represents $(\mathrm{KP} \times 1)$.

Table 1. Description of Covariates in the VAR Model

\begin{tabular}{lc}
\hline Variable definitions & Unit \\
\hline Trade openness as a percentage of GDP & $\%$ \\
The annual growth rate of GDP & $\%$ \\
The official exchange rate & LCU/US\$ \\
Tariff rate $^{\mathrm{b}}$ & $\%$ \\
\hline
\end{tabular}

Notes: a is calculated by a ratio between local currency unit and US dollar (LCU/US\$)

$\mathrm{b}$ is the average tariff rate applied for all products

In this study, the procedure of a VAR model includes six steps, consisting of (1) performing the unit root test; (2) determining lag length; (3) estimating the VAR model; (4) testing the Granger causality; (5) checking the stability of eigenvalues; and (6) implementing the Johansen test for co-integration. The VAR model is estimated by the Stata MP 14.2 software. 


\section{Results and Discussion}

Trade Openness, Economic Growth, Exchange Rate and Tariff Rate in Northeast Asia: An Overview

Trade openness is dominated by Korea, followed by China and Japan. In 2017, the rate of trade openness for Korea reached 80 percent, which was doubled higher than that of China. This implies the importance of trade openness to economic growth in Northeast Asian countries, especially in Korea (Figure 1).

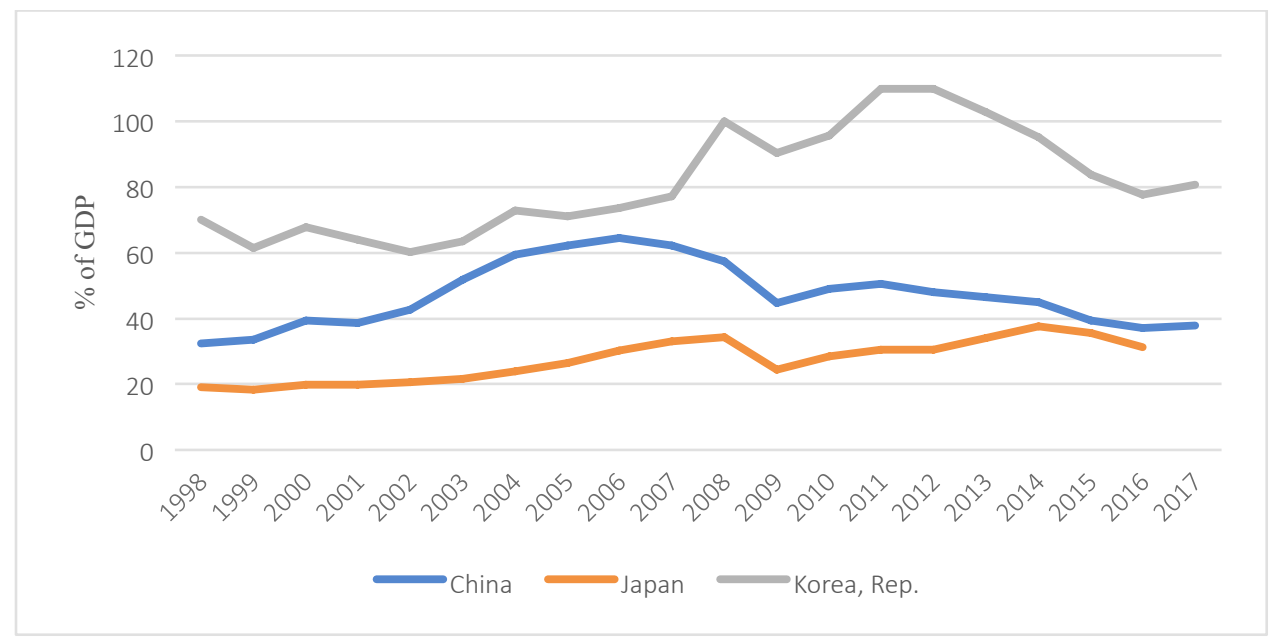

Figure 1. Trade Openness of Selected Countries in Northeast Asia Source: World Bank, 2019

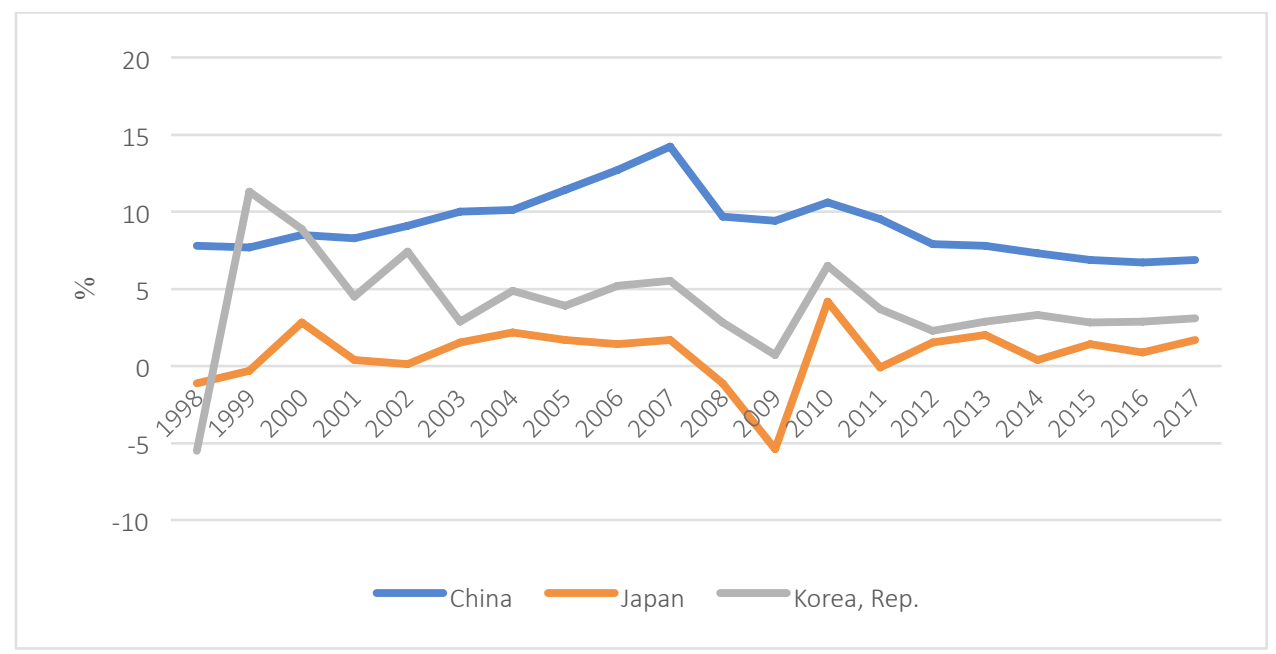

Figure 2. Annual GDP Growth Rate of Selected Countries in Northeast Asia

Source: World Bank, 2019

China had the strongest GDP growth rate for the last two decades (1998-2017), followed by Korea and Japan. In 2017, GDP growth rate of China accounted for nearly 7 percent, which was more than doubled higher than that of Korea. In 1998 and 2009, GDP growth rates of both Korea and Japan were very low, even accounted for minus values because of adverse effects of Asian financial crises (Figure 2). 


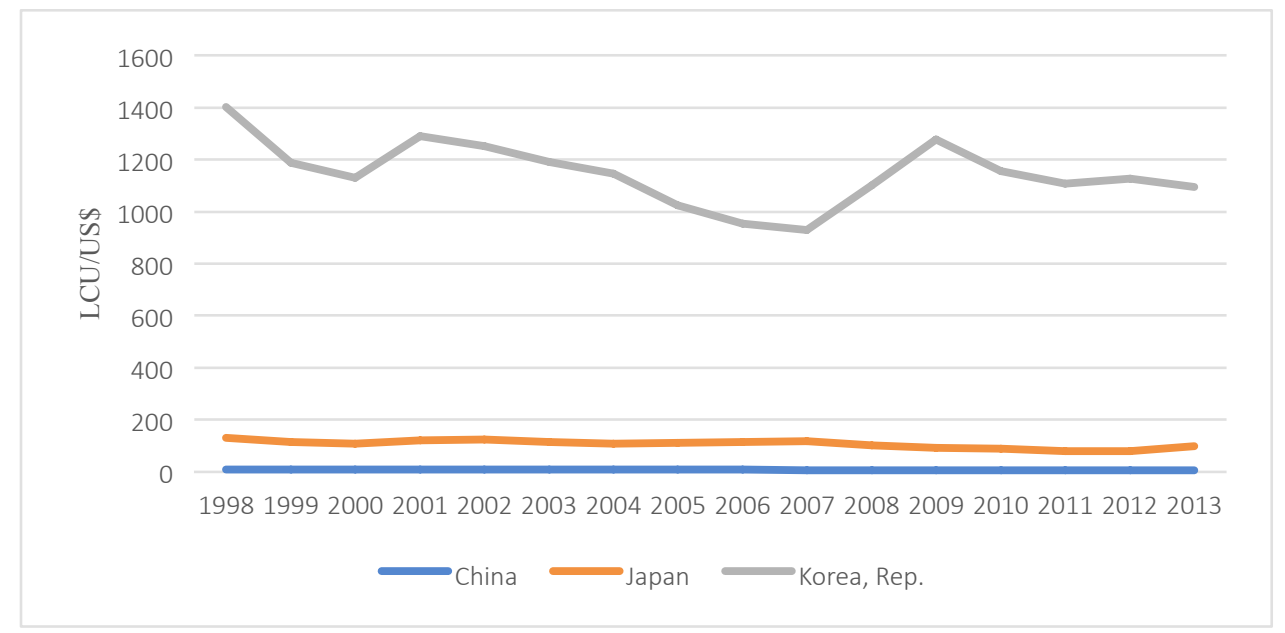

Figure 3. Official Exchange Rate of Selected Countries in Northeast Asia

Source: World Bank, 2019

The official exchange rate of China was lowest for the period 1998-2013 because this country tended to impose a low exchange rate by devaluating the domestic currency in order to accelerate its exports. This suggests that economic growth of China heavily depends upon exports rather than domestic consumption (Figure 3).

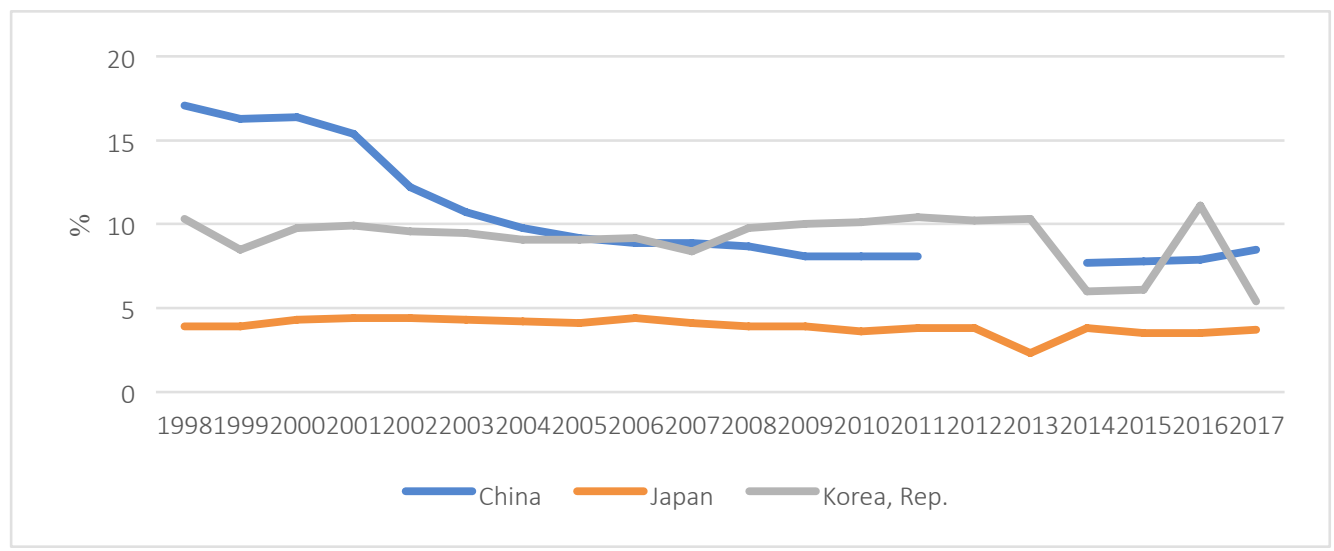

Figure 4. The Average Tariff Rate for All Products of Selected Countries in Northeast Asia

Source: World Bank, 2019

For the last two decades (1998-2017), the tariff rate of China decreased by about a half from about 17 percent in 1998 to 8.5 percent in 2017. Similarly, the tariff rate of Korea declined by nearly a half from about 10 percent in 1998 to 5.4 percent in 2017. However, the tariff rate of Japan was nearly stable at under 4 percent in the same period (Figure 4).

Table 2. Characteristics of Trade Openness, Economic Growth, Exchange Rate and Tariff Rate of Selected Countries in Northeast Asia

\begin{tabular}{lcccc}
\hline Variable & Mean & SD & Min & Max \\
\hline Trade openness & 51.50 & 25.87 & 0 & 110 \\
Annual GDP growth rate & 4.64 & 4.24 & -5.5 & 14.2 \\
Official exchange rate & 336.74 & 499.23 & 0 & 1401.4 \\
Tariff rate & 7.50 & 3.76 & 0 & 17.1 \\
\hline
\end{tabular}

Source: Author's calculation, 2019

Note: SD denotes standard deviation 
The average rate of trade openness and annual GDP growth of three countries account for 51.5 percent and 4.6 percent, respectively. Exchange rate and tariff rate account for 336 and 7.5 percent, respectively (Table 2).

The Relationship between Trade Openness, Economic Growth, Exchange Rate and Tariff Rate in Northeast Asia

\section{Implementation of the Unit Root Test}

The unit root test is carried out to check the stationarity or non-stationarity of the time series variables (Adeola and Ikpesu, 2016). In this study, the Augmented Dickey-Fuller (ADF) test is used to examine the stationarity of trade openness, annual GDP growth rate, exchange rate and tariff rate with the hypothesis as follows:

Null hypothesis $\left(\mathrm{H}_{0}\right)$ : The variables contain a unit root

Alternative hypothesis $\left(\mathrm{H}_{\mathrm{a}}\right)$ : The variables do not contain a unit root

Table 3. The ADF Test for the Unit Root

\begin{tabular}{|c|c|c|c|}
\hline Variables & Level & $1^{\text {st }}$ difference & $2^{\text {nd }}$ difference \\
\hline \multirow[t]{6}{*}{ LnTrade openness } & T-statistic: -4.55 & T-statistic: -2.84 & T-statistic: -2.17 \\
\hline & P-value: 0.00 & P-value: 0.05 & P-value: 0.21 \\
\hline & Critical values: & Critical values: & Critical values: \\
\hline & 1\% level: -3.56 & 1\% level: -3.56 & 1\% level: -3.57 \\
\hline & 5\% level: -2.92 & 5\% level: -2.92 & 5\% level: -2.92 \\
\hline & 10\% level: -2.59 & 10\% level: -2.59 & 10\% level: -2.59 \\
\hline \multirow[t]{6}{*}{ LnGDP growth rate } & T-statistic: -3.52 & T-statistic: -2.62 & T-statistic: -1.85 \\
\hline & P-value: 0.00 & P-value: 0.08 & P-value: 0.35 \\
\hline & Critical values: & Critical values: & Critical values: \\
\hline & 1\% level: -3.56 & 1\% level: -3.56 & 1\% level: -3.57 \\
\hline & 5\% level: -2.92 & 5\% level: -2.92 & 5\% level: -2.92 \\
\hline & 10\% level: -2.59 & 10\% level: -2.59 & 10\% level: -2.59 \\
\hline \multirow[t]{6}{*}{ LnExchange rate } & T-statistic: -2.26 & T-statistic: -2.32 & T-statistic: -2.44 \\
\hline & P-value: 0.18 & P-value: 0.16 & P-value: 0.12 \\
\hline & Critical values: & Critical values: & Critical values: \\
\hline & 1\% level: -3.56 & 1\% level: -3.56 & 1\% level: -3.57 \\
\hline & 5\% level: -2.92 & 5\% level: -2.92 & 5\% level: -2.92 \\
\hline & 10\% level: -2.59 & 10\% level: -2.59 & 10\% level: -2.59 \\
\hline \multirow[t]{6}{*}{ LnTariff rate } & T-statistic: -3.41 & T-statistic: -3.45 & T-statistic: -2.66 \\
\hline & P-value: 0.01 & P-value: 0.00 & P-value: 0.08 \\
\hline & Critical values: & Critical values: & Critical values: \\
\hline & 1\% level: -3.56 & 1\% level: -3.56 & 1\% level: -3.57 \\
\hline & 5\% level: -2.92 & 5\% level: -2.92 & 5\% level: -2.92 \\
\hline & 10\% level: -2.59 & 10\% level: -2.59 & 10\% level: -2.59 \\
\hline
\end{tabular}

Source: Author's calculation, 2019

Results show that we cannot reject the null hypothesis because P-values of all variables are greater than critical values at $1 \%, 5 \%$, and $10 \%$, respectively and these imply that variables exhibit a unit root (Table 3). 


\section{Determination of the Lag Length}

The objective of this step is to specify the optimal lag for the VAR model. If the lag is used too little, then the residual of the regression will not show the white noise process and as the result, the actual error could not be accurately estimated by the model (Suharsono et al., 2017).

Table 4. Selection of the Lag Length

\begin{tabular}{ccccccccc}
\hline Lag & LL & LR & df & $\mathrm{p}$ & FPE & AIC & HQIC & SBIC \\
\hline 0 & -302.77 & & & & 0.67 & 10.95 & 11.01 & 11.10 \\
1 & -229.28 & $146.99^{*}$ & 16 & 0.000 & $0.08^{*}$ & $8.90^{*}$ & $9.18^{*}$ & $9.62^{*}$ \\
2 & -222.14 & 14.26 & 16 & 0.579 & 0.11 & 9.21 & 9.72 & 10.52 \\
3 & -210.38 & 23.51 & 16 & 0.101 & 0.14 & 9.37 & 10.10 & 11.25 \\
4 & -199.19 & 22.38 & 16 & 0.131 & 0.17 & 9.54 & 10.49 & 12.00 \\
\hline
\end{tabular}

Notes: *denotes lag order selected by the criterion; LL means log likelihood values; LR represents sequential modified LR test statistics; FPE denotes final prediction error; AIC means Akaike information criterion; HQIC represents Hannan-Quinn information criterion; and SBIC means Schwarz's Bayesian information criterion.

Source: Author's calculation, 2019

As seen in Table 4, results suggest that the optimal lag length in this case is the lag 1 (the number of lag is equal to 1) because this value is recommended by FPE, AIC, HQIC and SBIC indicators. Therefore, lag 1 is chosen to run the VAR model in the next step.

\section{Estimation of the VAR Model}

We found that GDP growth rate has a positive relationship with trade openness. Tariff rate positively affects both GDP growth rate and exchange rate. However, trade openness has a negative effect on exchange rate (see details in Table A1 of the appendices).

\section{Testing the Granger Causality}

The goal of the Granger causality is to assess the predictive capacity of a single variable on other variables (Musunuru, 2017). In this research, hypotheses need to be tested as follows:

Testing the relationship between trade openness and other variables:

Null hypothesis $\left(\mathrm{H}_{0}\right)$ : Trade openness does not cause GDP growth rate, exchange rate and tariff rate

Alternative hypothesis $\left(\mathrm{H}_{\mathrm{a}}\right)$ : Trade openness causes GDP growth rate, exchange rate and tariff rate

Testing the relationship between GDP growth rate and other variables:

Null hypothesis $\left(\mathrm{H}_{0}\right)$ : GDP growth rate does not cause trade openness, exchange rate and tariff rate

Alternative hypothesis $\left(\mathrm{H}_{\mathrm{a}}\right)$ : GDP growth rate causes trade openness, exchange rate and tariff rate

Testing the relationship between exchange rate and other variables:

Null hypothesis $\left(\mathrm{H}_{0}\right)$ : Exchange rate does not cause trade openness, GDP growth rate and tariff rate 
Alternative hypothesis $\left(\mathrm{H}_{\mathrm{a}}\right)$ : Exchange rate causes trade openness, GDP growth rate and tariff rate

Testing the relationship between tariff rate and other variables:

Null hypothesis $\left(\mathrm{H}_{0}\right)$ : Tariff rate does not cause trade openness, GDP growth rate and exchange rate

Alternative hypothesis $\left(\mathrm{H}_{\mathrm{a}}\right)$ : Tariff rate causes trade openness, GDP growth rate and exchange rate

Table 5. Results of the Granger Causality Wald Test

\begin{tabular}{lcc}
\hline Directional Relationship & Probability & Conclusion \\
\hline Trade openness $\longrightarrow$ GDP growth rate & $0.02<0.05$ & Reject $\mathrm{H}_{0}$ \\
Trade openness $\longrightarrow$ Exchange rate & $0.01<0.05$ & Reject $\mathrm{H}_{0}$ \\
Trade openness $\longrightarrow$ Tariff rate & $0.20>0.05$ & Accept $\mathrm{H}_{0}$ \\
GDP growth rate $\longrightarrow$ Trade openness & $0.11>0.05$ & Accept $\mathrm{H}_{0}$ \\
GDP growth rate $\longrightarrow$ Exchange rate & $0.23>0.05$ & Accept $\mathrm{H}_{0}$ \\
GDP growth rate $\longrightarrow$ Tariff rate & $0.07>0.05$ & Accept $\mathrm{H}_{0}$ \\
Exchange rate $\longrightarrow$ Trade openness & $0.00<0.05$ & Reject $\mathrm{H}_{0}$ \\
Exchange rate $\longrightarrow$ GDP growth rate & $0.52>0.05$ & Accept $\mathrm{H}_{0}$ \\
Exchange rate $\longrightarrow$ Tariff rate & $0.02<0.05$ & Reject $\mathrm{H}_{0}$ \\
Tariff rate $\longrightarrow$ Trade openness & $0.27>0.05$ & Accept $\mathrm{H}_{0}$ \\
Tariff rate $\longrightarrow$ GDP growth rate & $0.12>0.05$ & Accept $\mathrm{H}_{0}$ \\
Tariff rate $\longrightarrow$ Exchange rate & $0.31>0.05$ & Accept $\mathrm{H}_{0}$ \\
\hline
\end{tabular}

Source: Author's calculation, 2019

There is a directional relationship running from trade openness to GDP growth rate and exchange rate; and from exchange rate to trade openness and tariff rate (Table 5).

\section{Examination of Eigenvalue Stability}

The purpose of this assignment is to check stability of the eigenvalues in the VAR model. All the eigenvalues lie inside the unit circle and we can conclude that the VAR model satisfies stability condition (Figure 5). 


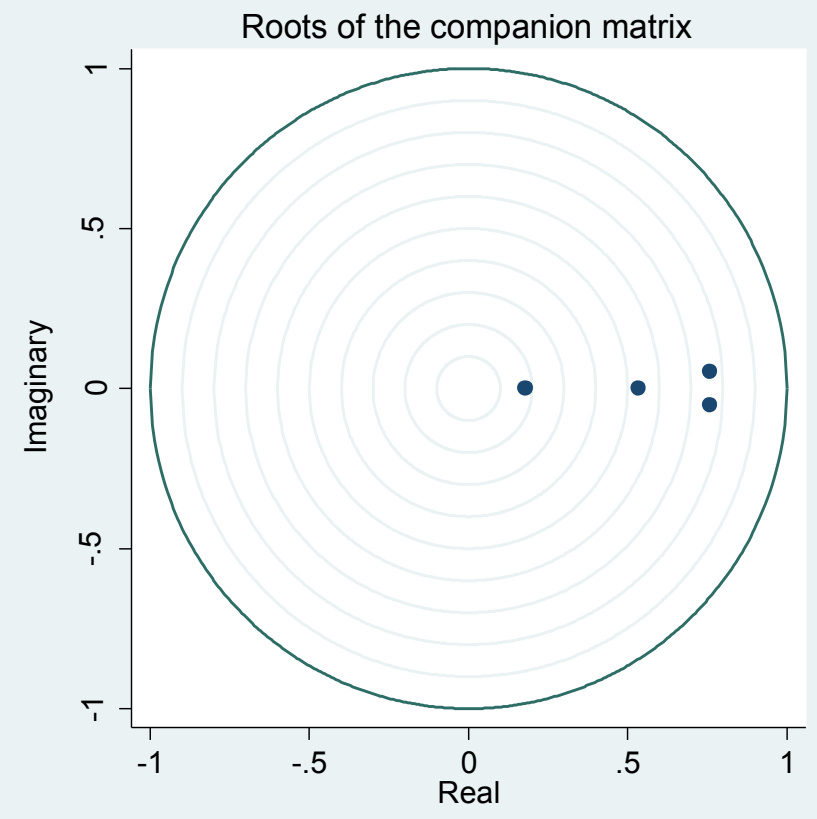

Figure 5. Checking the Stability of Eigenvalues in the VAR Model

Source: Author's calculation, 2019

\section{Performance of the Johansen Co-integration Test}

The Johansen co-integration test is performed in order to examine the long-run relationship among variables. If variables are co-integrated, it suggests that there is a long term relationship among variables (Musunuru, 2017).

The hypothesis to be tested can be identified as follows:

Null hypothesis $\left(\mathrm{H}_{0}\right)$ : There is no co-integration among variables

Alternative hypothesis $\left(\mathrm{H}_{\mathrm{a}}\right)$ : There is co-integration among variables

In this study, the Johansen co-integration test is carried out by trace statistic test. Trace test is a likelihood-ratio-type test, which operates under different assumptions in the deterministic part of the data generation process (Lutkepohl et al., 2001).

Table 6. Results of Trace Statistic in the Johansen Co-integration Test

\begin{tabular}{cccccc}
\hline Maximum Rank & LL & Eigenvalue & Trace Statistic & $\begin{array}{c}5 \% \text { Critical } \\
\text { Value }\end{array}$ & $\begin{array}{c}1 \% \text { Critical } \\
\text { Value }\end{array}$ \\
\hline 0 & -257.69 & & 56.57 & 47.21 & 54.46 \\
1 & -245.17 & 0.350 & $31.53^{* 1}$ & 29.68 & 35.65 \\
2 & -235.60 & 0.281 & $12.38^{* 5}$ & 15.41 & 20.04 \\
3 & -231.99 & 0.116 & 5.18 & 3.76 & 6.65 \\
4 & -229.40 & 0.085 & & & \\
\hline
\end{tabular}

Source: Author's calculation, 2019

Note: ${ }^{*}$ and ${ }^{*}$ denote the number of co-integrations (ranks) chosen to accept the null hypothesis at $1 \%$ and $5 \%$ critical values, respectively 
As seen in Table 6, we cannot reject the null hypothesis in the rank one (one co-integration) because trace statistic is less than $1 \%$ critical value $(31.53<35.65)$ and in the rank two (two cointegrations) because trace statistic is less than $5 \%$ critical value $(12.38<15.41)$. These imply that there is a co-integration among variables at $1 \%$ critical value and two co-integrations among variables at $5 \%$ critical value.

\section{Discussion}

We found that GDP growth rate has a positive relationship with trade openness and this implies that an increase in GDP leads to a higher rate of trade openness. Tariff rate positively affects both GDP growth rate and exchange rate and these suggest that a higher tariff rate generates higher output and exchange rate. However, trade openness has a negative effect on exchange rate and this reflects that growth of trade openness leads to a lower exchange rate. The growth of Northeast Asian economies depends on exports rather than domestic consumption. For instance, a higher level of economic integration contributes to the growth of exports of China (Chou et al., 2015). The Government of the Republic of Korea continues to support export-oriented development strategy and promoted technology intense industries for the past decades (Turan and Karakas, 2016). Unlike China and Korea that have used foreign economic policy as an instrument to reform domestic and enhance productivity, Japan has used bilateral deals largely as political and strategic tools (Armstrong and Drysdale, 2014). A negative relationship between trade openness and exchange rate reflects the return of trade protectionism in countries and re-adjustment of domestic currency values compared to the US dollar in recent years.

\section{Conclusion and Policy Implications}

The aim of this article is to examine the relationship between trade openness, economic growth, exchange rate and tariff rate in three Northeast Asian countries from 1998 to 2017. We found that GDP growth rate has a positive relationship with trade openness. Tariff rate positively affects both GDP growth rate and exchange rate. However, trade openness has a negative effect on exchange rate. We also found that there is a directional relationship running from trade openness to GDP growth rate and exchange rate; and from exchange rate to trade openness and tariff rate. There is a long run relationship among variables.

Macro policies should be considered to accelerate economic growth and trade openness in Northeast Asia. First, GDP should be facilitated because it contributes to the growth of trade openness. In order to deal with this assignment, employment creation and export enhancement along with consumption encouragement in the domestic market should be implemented because these contribute to the growth of economies. Second, tax policies should be effectively and carefully implemented because an increase of tariff rate leads to the growth of GDP. For example, better tax administration assists to enhance revenue collection by reducing tax avoidance and evasion, including by influencing people's willingness to pay taxes. According to the survey of the United Nations, by 2018, in Asia and the Pacific, a one-point increase in the tax administration index is associated with a tax revenue increase of 0.15 percent of GDP (United Nations, 2018). Finally, the economies like China and Korea, which depend heavily on exports, should construct long term strategies to reduce negative effects of trade protectionism because trade barriers can disrupt cross-border production networks and therefore it influences on not only long-term investment but also productivity growth. 


\section{References}

Adeola, O., \& Ikpesu, F. (2016). An empirical investigation of the impact of bank lending on agricultural output in Nigeria: A vector autoregressive (VAR) approach. The Journal of Developing Areas, 50(6), 89-103.

Armstrong, S., \& Drysdale, P. (2014). Japan's foreign economic policy strategies and economic performance. Working Paper Series No. 340. Center on Japanese Economy and Business. Columbia Business School.

Balavac, M., \& Pugh, G. (2016). The link between trade openness, export diversification, institutions and output volatility in transition countries. Economic Systems, 40(2), 273287.

Cantah, G. W., Brafu-Insaidoo, G. W., Wiafe, E. A., \& Adams, A. (2018). FDI and trade policy openness in Sub-Saharan Africa. Eastern Economic Journal, 44(1), 97-116.

Cetin, M. (2016). The impact of energy consumption, trade openness and financial development on economic growth: Empirical evidence from Turkey (1980-2014). European Journal of Economic Studies, 18(4), 459-469.

Chen, B., \& Feng, Y. (2001). Openness and trade policy in China: An industrial analysis. China Economic Review, 11(4), 323-341.

Chou, K. H., Chen, C. H., \& Mai, C. C. (2015). Factors influencing China's exports with a spatial econometric model. The International Trade Journal, 29(3), 191-211.

Hsiao, C. (2014). Analysis of panel data. Third Edition, Cambridge University Press, New York.

Idris, J., Yusop, Z., \& Habibullah, M. S. (2016). Trade openness and economic growth: A causality test in panel perspective. International Journal of Business \& Society, 17(2), 281290.

Kaushal, L. A., \& Pathak, N. (2015). The causal relationship among economic growth, financial development and trade openness in Indian economy. International Journal of Economic Perspectives, 9(2), 5-22.

Korea Institute for International Economic Policy (KIEP) (2017). Sustaining momentum for building a Northeast Asian economic community. Conference Proceeding 17-01. Northeast Asia Economic Forum.

Lütkepohl, H., Saikkonen, P., \& Trenkler, C. (2001). Maximum eigenvalue versus trace tests for the cointegrating rank of a VAR process. The Econometrics Journal, 4(2), 287-310.

Makhlouf, Y., Kellard, N. M., \& Vinogradov, D. (2015). Trade openness, export diversification, and political regimes. Economics Letters, 136, 25-27.

Marelli, E., \& Signorelli, M. (2011). China and India: Openness, trade and effects on economic growth. The European Journal of Comparative Economics, 8(1), 129-155.

Musunuru, N. (2017). Causal relationships between grain, meat prices and exchange rates. International Journal of Food and Agricultural Economics, 5(4), 1-10.

Park, I., \& Park, S. (2008). Reform creating regional trade agreements and foreign direct investment: Applications for East Asia. Pacific Economic Review, 13(5), 550-566.

Park, J. H. (2002). The East Asian model of economic development and developing countries. Journal of Developing Societies, 18(4), 330-353. 
Pfaff, B. (2008). VAR, SVAR and SVEC models: Implementation within R package vars. Journal of Statistical Software, 27(4), 1-32.

Suharsono, A., Aziza, A., \& Pramesti, W. (2017). Comparison of vector autoregressive (VAR) and vector error correction models (VECM) for index of ASEAN stock price, AIP Conference Proceedings 1913, 1, pp. 020032-1-020032-9. AIP Publishing. Doi: 10.1063/1.5016666. International Conference and Workshop on Mathematical Analysis and its Applications (ICWOMAA 2017).

Turan, T., \& Karakas, M. (2016). The effect of trade openness and income on the size of a government. Transylvanian Review of Administrative Sciences, 12(47), 164-178.

United Nations (2018). Economic and social survey of Asia and the Pacific 2018: Mobilizing finance for sustained, inclusive and sustainable economic growth. Economic and Social Commission for Asia and the Pacific. The United Nations 2018.

World Bank (2019). World Development Indicators. Annual GDP growth rate of selected countries in Northeast Asia. Available at: https://databank.worldbank.org/data/reports.aspx?source=2\&series=TG.VAL.TOTL.GD. ZS\&country=\# (accessed 10 April 2019).

World Bank (2019). World Development Indicators. Official exchange rate of selected countries in Northeast Asia. Available at: https://databank.worldbank.org/data/reports.aspx?source=2\&series=TG.VAL.TOTL.GD. ZS\&country=\# (accessed 10 April 2019).

World Bank (2019). World Development Indicators. The average tariff rate of selected countries in Northeast Asia. Available at: https://databank.worldbank.org/data/reports.aspx?source=2\&series=TG.VAL.TOTL.GD. ZS\&country=\# (accessed 10 April 2019).

World Bank (2019). World Development Indicators. Trade openness of selected countries in Northeast Asia. Available at: https://databank.worldbank.org/data/reports.aspx?source=2\&series=TG.VAL.TOTL.GD. ZS\&country=\# (accessed 10 April 2019). 


\section{Appendices}

Table A1. Estimation of the VAR Model

\begin{tabular}{lcccc}
\hline Variables & Coefficient & Standard Error & $\mathrm{t}$ & P-value \\
\hline LnTrade openness & & & & \\
LnTrade openness (L1) & 0.193 & 0.13 & 1.48 & 0.144 \\
LnGDP (L1) & $0.205^{* *}$ & 0.08 & 2.33 & 0.024 \\
LnExchange rate (L1) & $0.079^{* *}$ & 0.03 & 2.43 & 0.018 \\
Ln Tariff rate (L1) & 0.194 & 0.15 & 1.29 & 0.204 \\
Constant & $2.142^{* * *}$ & 0.43 & 4.93 & 0.000 \\
LnGDP & & & & \\
LnTrade openness (L1) & 0.274 & 0.17 & 1.59 & 0.118 \\
LnGDP (L1) & $0.468^{* * *}$ & 0.11 & 4.03 & 0.000 \\
LnExchange rate (L1) & -0.052 & 0.04 & -1.20 & 0.234 \\
Ln Tariff rate (L1) & $0.367^{*}$ & 0.19 & 1.85 & 0.070 \\
Constant & -0.903 & 0.57 & -1.58 & 0.121 \\
LnExchange rate & & & & \\
LnTrade openness (L1) & $-1.424^{* * *}$ & 0.29 & -4.75 & 0.000 \\
LnGDP (L1) & 0.129 & 0.20 & 0.64 & 0.525 \\
LnExchange rate (L1) & $0.919^{* * *}$ & 0.07 & 12.20 & 0.000 \\
Ln Tariff rate (L1) & $0.774^{* *}$ & 0.34 & 2.24 & 0.029 \\
Constant & $4.017^{* * *}$ & 0.99 & 4.03 & 0.000 \\
LnTariff rate & & & & \\
LnTrade openness (L1) & -0.105 & 0.09 & -1.11 & 0.271 \\
LnGDP (L1) & 0.098 & 0.06 & 1.54 & 0.129 \\
LnExchange rate (L1) & 0.024 & 0.02 & 1.01 & 0.315 \\
Ln Tariff rate (L1) & $0.647^{* * *}$ & 0.10 & 5.92 & 0.000 \\
Constant & $0.830^{* *}$ & 0.31 & 2.64 & 0.011 \\
\hline
\end{tabular}

Source: Author's calculation, 2019

Notes: L1 means $\operatorname{lag} 1 ;{ }^{* * *},{ }^{* *}$ and ${ }^{*}$ denote statistical significance at $1 \%, 5 \%$, and $10 \%$, respectively 